Submarine Mock Valleys

Author(s): W. M. Davis

Source: Geographical Review, Vol. 24, No. 2 (Apr., 1934), pp. 297-308

Published by: American Geographical Society

Stable URL: https://www.jstor.org/stable/208795

Accessed: 15-11-2019 00:07 UTC

JSTOR is a not-for-profit service that helps scholars, researchers, and students discover, use, and build upon a wide range of content in a trusted digital archive. We use information technology and tools to increase productivity and facilitate new forms of scholarship. For more information about JSTOR, please contact support@jstor.org.

Your use of the JSTOR archive indicates your acceptance of the Terms \& Conditions of Use, available at https://about.jstor.org/terms 


\title{
SUBMARINE MOCK VALLEYS
}

\author{
W. M. Davis
}

T

HOSE peculiar features found in the sea floors of continental margins and generally known as "submarine valleys" have been confidently interpreted by a number of geologists as the product of streaming and weathering during a recent epoch of emergence and as not yet obliterated by marine deposition during a still more recent time of submergence. ${ }^{1}$ It is not intended to imply by what here follows that the method of submarine-valley formation thus outlined is either impossible or non-operative. The object of this essay is to point out certain difficulties in the way of the general acceptance of that method, thus supplementing the writings of several authors cited below, and at the same time to suggest the consideration of other methods for the production of submarine valleys. It is desired also to urge the maintenance of an open mind on the problem, inasmuch as certain collateral but essential consequences of the aboveoutlined method of submarine-valley production have not yet been verified; indeed, have not even been considered in the writings of some of its more convinced advocates. Nor have alternative methods been given the hospitable and thorough discussion that Chamberlin has so well shown to be essential in impartial and decisive investigation. ${ }^{2}$

A submarine valley should be regarded as merely an element in the geological history of its coastal region, and its explanation should therefore be consistent with that history. Moreover, the larger part of the history must be based on the study of the visible surface of the coastal land area, the form of which can be accurately mapped, the structure of which can be fairly well inferred from surface outcrops, and the internal and external processes affecting which are fairly well understood; while the sea floor is, as a rule, imperfectly charted, its structure is unknown except for a veneer of surface sediments, and its processes are still uncertain.

\section{Submarine Mock Valleys of the Santa Monica Coast}

In connection with a study of the coastal development of the Santa Monica Mountains in southern California my attention has

1 A variant of this interpretation recently proposed by Francis P. Shepard is to the effect that the valleys were eroded during a more ancient epoch of emergence, then filled and obliterated by the deposition of marine sediments during a sufficiently long period of submergence, and lately revealed again by the downsliding of the sedimentary filling to greater depths. See his article "LandslideModifications of Submarine Valleys," Trans. Amer. Geophys. Union, Thirteenth Ann. Meeting, April 28 and 29, 1932, Washington, 1932, pp. 226-230. The same author has given an excellent summary of various hypotheses for the explanation of these features in "Submarine Valleys," Geogr. Rev., Vol. 23. 1933, pp. 77-89.

2 T. C. Chamberlin: The Method of Multiple Working Hypotheses, Journ. of Geol., Vol. 5, I897, pp. $837-848$. 
recently been directed to a stretch of the southern Californian sea floor where discovery has been made of three lowerings and depositional withdrawals of the sea alternating with four rises and abrasional advances, which I believe were causally associated with as many glacial and nonglacial epochs of Pleistocene time. It was there found that during the last epoch (probably during the last two epochs) of lowered sea level a number of the mountain streams eroded their valleys to a moderate depth below present sea level and for a moderate distance forward from the mountains across a belt of weak Miocene beds-a belt that had been faulted down along the southern mountain border and that then constituted a lowland plain but is now the near-shore part of the sea floor. But it was also found that the parts of those valleys now below sea level had been completely obliterated by marine deposition during the postglacial rise of sea level to the present shore line at the base of the abraded mountain cliffs. ${ }^{3}$

The sea floor in the neighborhood of the mountains nevertheless possesses, as has been shown by Davidson, several well defined submarine valleys, one of which, lying about Io miles west of the mountains off the Hueneme beach of the Oxnard plain, is of interest as being the first discovered example of its kind on the Californian coast. ${ }^{4}$ But all these valleys are continued in Davidson's contours to depths of 200 or 300 fathoms, which is from 3 to 6 times deeper than the estimate adopted by Daly for the Glacial lowering of sea level. ${ }^{5}$

There are, therefore, two points to be noted regarding the submarine valleys of the Santa Monica coast. The first point is that no evidence is found in the mountains to indicate a recent upheaval and subsidence by any such measure as $\mathrm{I} 200$ or $\mathrm{I} 800$ feet. Hence the valleys there charted by Davidson are far below the reach of erosional production during any known epoch of coastal emergence. Hoots states that the first deformation of the mountain rocks was of midMiocene date; that after suffering erosional reduction to low relief in later Tertiary time the worn-down mass was broadly uplifted 2000 or 3000 feet to its present altitude near the end of Pleistocene time; and that during and since that uplift the resulting highland has been submaturely dissected. ${ }^{6}$ It may be pointed out in this connection that the belt of weak Miocene beds, alluded to above as bordering

${ }^{3}$ W. M. Davis: Glacial Epochs of the Santa Monica Mountains, California, Bull. Geol. Soc. of America, Vol. 44, I933, pp. I04I-I I33.

4 George Davidson: The Submerged Valleys of the Coast of California, U. S. A., and of Lower California, Mexico, Proc. California Acad. of Sci., 3rd Ser. (Geology), Vol. I, I 897-1904, pp. 73-103. It is noteworthy that this experienced hydrographer first called these features "submarine valleys" but later designated them as "submerged valleys." He did not explicitly state them to be the work of streams during a former emergence of the sea floor, apparently because that origin was in his opinion too manifest to need statement, for he wrote: "The first discovery of a distinct valley in the submerged surface of the earth bordering the coast of California was made in 1855 by the U. S. Coast Survey."

${ }^{5}$ R. A. Daly: Swinging Sealevel of the Ice Age, Bull. Geol. Soc. of America, Vol. 40, 1929, pp. 72 I734.

${ }^{6} \mathrm{H}$. W. Hoots: Geology of the Eastern Part of the Santa Monica Mountains, Los Angeles County, California, U. S. Geol. Survey Professional Paper $165-C$, 1931. 
the mountains on the south, was conceivably faulted down after having been previously uplifted with the mountain mass and that the valleys that had been eroded across the belt during its existence as an upland were submerged by the downfaulting. But in that case there should now be as many submerged valleys as there are goodsized mountain streams, and there are not. Only one submerged valley is found that might possibly be of this origin, and there should be at least ten or twelve. Moreover, the Hueneme submerged valley fronts the Oxnard plain, which appears not to have suffered uplift with the mountains but to have long been the site of subsidence. Hence this explanatory scheme is inapplicable.

The second point is that ordinary depositional processes, which have unquestionably been acting to build up the shallower sea floor adjoining the submarine valleys, ought to have obliterated the inner parts at least of the existing submarine valleys, unless some marine process of opposite nature and still in operation had kept them empty. Hence, in view of the great improbability that the submarine valleys off the Santa Monica coast are truly valleys of subaerial erosion, I propose to call them submarine mock valleys.

\section{Views of Earlier Observers}

The foregoing conclusions, to which I was led by local study, substantially repeat the conclusions reached for this coast about 30 years ago by Ritter and Tangier Smith, to whose brief articles my attention has recently been directed. Ritter dredged in the Vincente (or Redondo) submarine valley, which lies some fifteen miles south of the Santa Monica coast, and he was there led to the belief that inshore material is carried into that valley in large quantities and that such "valleys are natural channels through which currents flow, at times at least, from the shore out to deeper water." 7 Tangier Smith, quoting Ritter, gave a well reasoned general discussion of the problem, showing sound reasons for doubting the commonly accepted method of submarine-valley production above outlined, and concluding that "the majority of the submarine channels of the California coast have been formed, or are at least kept open, by some cause now in operation." 8

Ten years earlier Dana had already made a protest against the too facile acceptance of a subaerial origin for one of the most famous of all submarine valleys, that of the Hudson River. He wrote: "It may be that the outflowing tide from New York Bay and from the adjoining parts of the shores of Long Island and New Jersey may have combined their forces along a diagonal line crossing the shallow

${ }^{7}$ W. E. Ritter: A Summer's Dredging on the Coast of Southern California, Science, Vol. I5 (N.S.), 1902, pp. 55-65; reference on p. 59.

${ }^{8}$ W. S. Tangier Smith: The Submarine Valleys of the California Coast, Science, Vol. I5 (N.S.), I902, pp. 670-672; reference on p. 670. 
Atlantic border region, and, by scour only, have given the existing depth as well as course to the larger part of the channel." 9 Oceanographers have not given sufficient heed to this suggestion.

It has been pointed out by Trask that the Hueneme submarine valley referred to above is floored with fine sediment $; ;^{10}$ and the presence of such sediment might be appealed to as showing that no submarine agency capable of preventing deposition is in operation there. But it may also be argued that, if the agency of prevention is an outflowing bottom current, effective chiefly during great storms, fine sediments of the kind that are then swept away would be redeposited during a following spell of fine weather, when soundings are usually made. The case would be analogous to that of a river, which scours away the sediments of its bed while in flood but lays down similar sediments again as the flood subsides; or to that of shore waves, which in calm weather play about on beaches, the detritus of which they lift and shift during storms; or to that of water erosion in the desert, which is inoperative for years of no rainfall but which becomes violently active for a few hours after a cloud-burst.

\section{Localization of Sea-floor Currents}

As to the possibility of localizing a submarine current sufficiently to enable it to prevent deposition or even to accomplish some erosional excavation along a relatively narrow trough, it may be noted that the four best defined mock valleys-Hueneme, Mugu, Point Dume, and Vincente (or Redondo) - of the Santa Monica region shown on Davidson's Chart VI are all associated with irregularities of the present shore. The first two are near pronounced southeastward inturns of a mile in the heavy sand beach of the Oxnard plain, and these inturns indicate the prevalence of a dominant southeastward longshore current, the presence of which is shown also by the direction of beach drift. It may therefore be inferred that a backset eddy current, frictionally driven by, and therefore in gear with, the main shore current, is there located; and it should be further inferred that such an eddy current may interfere with the main current sufficiently to compel it to give off a slow outflowing bottom current. The fact that the two mock valleys here considered do not agree precisely in position with the beach inturns may perhaps be explained by a shift of the inturns in the direction of the main current, such as is well known to take place; while the mock valleys, once begun, are likely to retain their position. This hypothesis is offered merely as a tentative suggestion; but it is of the kind that should, I believe, be made in searching

${ }^{9}$ J. D. Dana: Long Island Sound in the Quaternary Era, with Observations on the Submarine Hudson River Channel, Amer. Journ. of Sci., Ser. 3, Vol. 40, 189o, pp. 425-437; reference on p. 432.

10 P. D. Trask: Origin and Environment of Source Sediments of Petroleum, Houston, Tex., I932, pp. 90 and 122 . 
for the recondite cause of these singular submarine features. The difficulty remains of testing its verity and sufficiency.

The other two mock valleys-Point Dume and Vincente-here under consideration are on the up-current side of pronounced salients of the coast: one of these is Point Dume, which stands forth two miles from the general shore line of the Santa Monica Mountains at the mid-length of their coast; the other is the large fault-block promontory of San Pedro, some twenty miles south of the mountains. It may be inferred that these coastal salients localize outflowing sea-floor currents that are deflected from the dominant surface current; also, that when accelerated at time of violent storms such deflected sea-floor currents are capable of drifting large quantities of inshore detritus seaward along their trough, as Ritter announced.

\section{The Value of Outrageous Theories}

If any of these inferences seem outrageously improbable at first reading, let the grounds for their outrageousness be deliberately inquired into; and, when they are found, let the necessity of believing them be seriously questioned. What at first appears outrageous may, when those grounds are deep-plowed, possibly come to be regarded as "intrageous"; and the more deeply they are plowed the more reasonably "intrageous" the outrageous inferences may come to appear. ${ }^{11}$ Consideration should thus be given not only to the apparently fantastic idea of localized outflowing sea-floor currents, chiefly active during storms, but to all other inventible agencies that come forth when the imagination is ransacked for them. Each invented agency should be carefully scrutinized as to its availability before we fall back on anything so outrageous as the recent upheaval of our littoral sea floors through any such measures as 2000,5000 , or even I2,000 feet, which some submarine mock valleys demand on the theory that they represent normal valleys of subaerial erosion.

Surely it ought not to be necessary today to repeat that the replacement of previously accepted conclusions by new conclusions, which at the time of their proposal were almost universally regarded as outrageous, has long marked the course of scientific progress. Witness our now accepted beliefs about the rotation of the earth, its revolution around the sun, its great age, the antiquity of man, the evolution of life forms, and the recent glaciation of large continental areas. And, if it is objected that earth science is now so well established that no outrageous modifications of its generally accepted conclusions are to be expected, let it be seriously asked whether submarine processes deserve to be so considered.

11 See an essay by the author on "The Value of Outrageous Geological Hypotheses," Science, Vol. 63 (N.S.), 1926, pp. $463-468$. 
Are we justified, for example, in rejecting a slow process of submarine erosion by which mock valleys could actually be excavated in the slopes of the sea floor? May not the rocks in certain parts of the submarine continental slopes be slowly disintegrated by the highpressure sea water? May not an outflowing sea-floor current, branching from a surface current because of some peculiarity of coastal configuration and accelerated during surface storms, be competent to remove the leached slime from rocks thus disintegrated? Would such action be more remarkable than the removal of silica from decomposed feldspar in rain-water solution during the production of laterite on subaerial peneplains, the degradation of which requires hundreds of thousands of years? If such submarine erosion (or "'marosion," as it might be called) is possible at all, might it not, in the course of a geological period, produce significant changes of seafloor configuration? These are some of the outrageous possibilities that call for investigation.

\section{A Remarkable Example of Submarine Degradation}

This section is given to an example of submarine degradation at a surprising depth off the northeastern coast of Australia. The facts concerned came to my notice through the writings of Alexander Agassiz, the most widely experienced observer of coral reefs the world has known, and of Charles Hedley, expert biological and geological observer of the Australian coast.

Agassiz wrote as follows: "It is a curious coincidence . . . that at Breaksea Spit [near the southern end of the Great Barrier Reef of Australia], as well as at Cape Florida [the northern end of the Key West coral reefs], we should find the encroachment of the silicious sands, in one case coming from the north along the [sand reefs on the eastern] coast of Florida, and in the other coming from the south along the shores of [the sand reef that constitutes] Frazer Island [on the coast of Queensland, Australia], gradually prevent the farther northern and southern extension of coral reefs in the two regions. . . . It is evident that the corals upon the spit are dead, and that they probably have been killed by the encroachment of the silicious sands creeping northward . . . This silicious sand is constantly overwhelming the few corals which manage to get established on the spit, and prevent their further growth, much as the silicious sands of Cape Florida are constantly mixing with the calcareous sand derived from the coral reefs immediately to the south of it." 12 In other words, the poleward extension of the Australian and Floridian coral reefs is prevented by the equatorward drift of sand from adjacent sand reefs.

12 Alexander Agassiz: A Visit to the Great Barrier Reef of Australia in the Steamer "Croydon," during April and May, 1896, Bull. Museum of Comp. Zoöl. at Harvard College, Vol. 28 (Geol. Ser., Vol. 3), 1895-1898, pp. 93-148; reference on pp. ro4-ro5. 
About I5 years after Agassiz's visit to Australia Hedley called attention to a remarkable increase in the depth of the sea floor in the neighborhood of the above-mentioned Breaksea Spit, over an area of more than Ioo square miles, as shown by the consistent differences between soundings taken by two British surveying ships, the first about I 869, the second in I904. The captain of the second vessel "found that from five to ten miles north of Break-Sea Spit the conformation of the sea-floor had entirely altered during the thirty-four years that had elapsed since the previous survey. Where his predecessors had found twenty to thirty fathoms he measured from two to three hundred fathoms." The captain ascribed the alteration of depth to excavation by "a powerful southerly-going current," thus failing to note that a current in that direction would carry calcareous sand southward, instead of carrying siliceous sand northward, as Agassiz states is the case; but Hedley was inclined to ascribe the deepening to a movement of the earth's crust, although, as he noted that no accompanying change had taken place in the shore line, this explanation must have seemed doubtful. ${ }^{13}$

It thus appears that Agassiz found that the sands, drifting northward, were smothering the corals at the end of the Great Barrier Reef but that he had no knowledge of the deepening of the adjacent sea floor, which had not been discovered at the time of his visit. Hedley, on the contrary, knew of the sea-floor deepening but did not associate it with the smothering of the corals at the reef end, although he noted that "conditions are really becoming very adverse for coral growth" thereabouts. But when the two groups of facts are considered together it is difficult not to associate them in the relation of cause and effect. It seems reasonable to suggest that, as long as corals and other reef builders thrive, the reef that they build will assume a submarine profile appropriate, on the one hand, to the constructive rate at which they contribute their calcareous skeletons to its building and, on the other hand, to the destructive rate at which the local waves and currents wear the reef away. But as soon as the reef builders are killed the destructive waves and currents will have it all their own way, and a change toward a submarine profile of their preference will go on apace.

It seems probable that an encroachment of this kind, by which sand reef has gained on coral reef, has been going on for a considerable part of postglacial time and that a large part of the 4oo-mile failure of the Great Barrier Reef to reach the southern limit of the coral seas is to be thus accounted for. It is, indeed, conceivable that a much greater encroachment of the same kind was accomplished during the last interglacial epoch, which was much longer than postglacial time,

13 C. Hedley: A Study of Marginal Drainage, Proc. Linnean Soc. of New South Wales, Vol. 36, I9II, pp. 13-39: reference on p. I7. 
and also that the siliceous sands found by a recent boring through the Great Barrier a good distance north of Breaksea Spit may be thus accounted for. This suggestion, it may be noted in passing, illustrates the complexities reached by the geological aspects of the coral-reef problem-complexities seldom taken into consideration by its zoölogical students.

However, both the pace at which the change has recently gone on in this instance and the depth to which it has reached are astonishing, so I wrote to the British Admiralty in London, asking whether the two sets of soundings in question could be accepted as trustworthy, and was assured in reply that they could be so considered. This instance of rapid and deep submarine degradation would seem to be the greatest authentic example of its kind. Before accepting it as a finality, however, it may be prudent to wait confirmation by a third set of soundings, which should show a northward extension of the previously discovered deepening, if the explanation here suggested is correct. Even if such changes in depth are excessive, changes of much slower rate have had plenty of time for the production of important modifications in the course of a geological period or epoch.

The moral of this story, as applied to submarine valleys, is clear. We must believe not only that efficient processes of degradation and transportation are at work on the sea floor at considerable depths but also that they will strive to modify sea-floor profiles enforced upon them by other agencies, such as crustal deformation, volcanic eruptions, deposition of clastic material from the lands, or reef building, and to reshape them either by degradation or by prevention of deposition.

\section{The Monterey Mock Valley}

The most remarkable submarine mock valley of the California coast is that heading in Monterey Bay, 70 miles south of Golden Gate. The progress of our knowledge concerning this valley is instructive. Its near-shore part was first contoured in I 897 on Davidson's Plate IX, where it is shown for about 18 miles offshore down to 800 fathoms, but the deeper contours along its southern side are there drawn on insufficient evidence, having been guided much more by theoretical preconceptions than by charted soundings.

Seventeen years later the valley was adventurously shown in suspiciously regular contour lines for every roo meters down to 3200 meters (about I 700 fathoms) 70 miles offshore on the San Francisco Bay sheet of the projected map of North America on a scale of I : I,ooo,ooo published by the U. S. Geological Survey; but the deeper contours must be largely imaginary because of lack of soundings then available to control them.

A noteworthy advance would seem to have been accomplished by 
the extended series of echo soundings made by the United States cruisers Hull and Corry in 1922 along the southern half of the California coast, the contoured depths thus determined being published by the U. S. Hydrographic Office on a colored chart (5194) in 1923: here the valley is shown down to 2000 fathoms about 65 miles offshore; but, as the location of the individual soundings is unfortunately not indicated on this chart, the trustworthiness of the contours cannot be judged. ${ }^{14}$ As far as Monterey Bay region alone is concerned, the configuration of the sea floor as determined by these echo soundings can be best studied on a special edition of Coast Survey chart 5402, issued by the Hydrographic Office, on which the position of the echo soundings and their contours is overprinted. ${ }^{15}$

The latest representation of the Monterey mock valley is on a detailed but as yet unpublished chart, showing a great number of accurately measured and located soundings (but not covering the inner part of the bay, which had previously been surveyed with sufficient accuracy), made by the Coast and Geodetic Survey in 1932, a copy of which has been generously sent me by the Director of that bureau. Here a well defined and noticeably sigmoid trough is shown with several short branches in its upper part and with a line of continuous descent from a depth of 500 fathoms at a distance of 15 nautical miles from the valley head near the shore down to 1900 fathoms at a distance of about 65 miles from the same point. The sea bottom at the lower end of the trough is not noticeably uneven; it certainly exhibits no back-slope basins and no huge sprawling mounds such as should be produced by a landslide of dimensions sufficient to empty the trough behind it.

14 It is regrettable also that the soundings made by the two cruisers were not corrected for their obliquity due to the slope of the sea floor, which in certain localities appears to be so great as to cause errors of about $\mathrm{r} 2$ per cent of the true depth, as well as significant errors of position. (See A. L. Shalowitz: Slope Corrections for Echo Soundings, U. S. Coast and Geodetic Survey Special Publ. No. I65, I930.) Moreover, the contours for the chart were not drawn by a hydrographer but by a topographer of the U.S. Geological Survey, who was presumably more familiar with the forms of the lands than with those of the sea floor. And, inasmuch as a certain rectangular area of over I80o square nautical miles in the deeper part of the valley has, apart from the soundings along its two longer sides, not a single indication of depth, the contours there drawn cannot be regarded as well certified, although they are given the same strength as elsewhere.

15 A study of this chart is, however, somewhat perplexing, for it seems to show that earlier soundings by the Coast Survey, printed in smaller figures, were not utilized in drawing the contours here shown. For example, at one point, near which 5 Coast Survey soundings are platted, the H. O. contour of 200 fathoms runs close to a C. S. sounding of 455 fathoms; and at another point the H. O. contour of 600 fathoms runs near a C. S. sounding of 320 fathoms. More disconcerting still is the discordance between the Hull and Corry soundings, taken every mile on lines ro miles apart square to the coast, and a later line of echo soundings run by the U. S. SS. Maryland in 1929, but on a line parallel to the coast, all these soundings being printed as if equally authentic. At one point where two lines of soundings cross about 25 miles southwest of Monterey, the earlier line consistently gives 850, 990, ro70, I I75, and I360 fathoms, while the later line gives with equal consistency $600,600,670,690$, and 795 . Here the middle soundings of both series are only half a mile apart, yet they differ from each other by an even 400 fathoms. A letter from the Hydrographic Office informs me that these discrepancies "can be best accounted for by probable errors in the ship's [Maryland] positions and incorrect depth values (the sonic values not corrected for velocity of sound in differing densities of water or for slope of bottom). The fixes for the lines of soundings taken by the Maryland while cruising along the coast, out of sight of land, and in thick weather, are not considered as reliable as those of the Hull and Corry." 
The trough is thus definitely shown to be a large and important feature of the continental slope. The confirmation of its existence given by these numerous and accurately located soundings must, indeed, be a satisfaction to those who had contoured it on earlier charts of fewer soundings; but so great is the irregularity of the latest and best contours that it is rather difficult to identify certain features previously shown by simpler contours. This suggests a point of importance: if the true explanation of a submarine valley depends on a fairly close knowledge of its form, very few of the deeper ones can be today considered well enough known to serve as a basis of study.

\section{Requirements for Subaerial Erosion}

If the Monterey mock valley is explained as a normal valley of subaerial erosion, two contrasted suppositions may be made as to the manner in which the submarine continental slope was temporarily upheaved. First, the upheaval may have involved little more than an upbending of the slope itself on a hinge line along the shore, without any equivalent upheaval of the present land area. In this case no great deepening of the land valleys would be needed, but the river that then eroded the valley would have had to maintain its course across the upbent offshore belt, and the upbending would therefore have to be slow. It would furthermore have to be rather long maintained, because the submarine trough that now exists there is broadly opened. But it is to be questioned whether any structural geologist will accept this strong though simple up-and-down style of deformation of a submarine belt alongside of an undisturbed land belt.

Second, the upheaval may have involved a fairly uniform elevation of a large coastal region, followed by a corresponding regional subsidence. In this case an immense deepening of the present land valleys, which mouth in the bay, along a good number of miles of their lower courses would result, if the upheaval were maintained long enough for the deepening and broadening of the now submarine part of the valley, and a correspondingly great refilling of the deepened land valleys would follow the regional subsidence of the land to its present level. The valley of the Salinas River, which enters Monterey Bay from an aggraded valley on the southeast, may have suffered some such changes; but that of the Pajaro River, which enters farther north from a narrow valley through the end of the mountains that limit the northern side of the bay, gives no indication of having been thus deepened and refilled.

\section{Geological History of Monterey Bay}

Instead of assuming coastal upheaval, erosion, and subsidence, let another assumption be made more consistent with what is known 
of the diastrophic history of the region. Let it be understood at the outset that Monterey Bay is not a drowned valley of subaerial erosion, like the beautiful branching bay of Port Jackson, New South Wales, on which Sydney stands. Monterey Bay is best explained as occupying the unfilled part of a gulf that took possession of a depressed land area, adjoining which on the north, east, and south the mountain ranges of today were individually uplifted in late geological time; after their predecessors had been worn down to moderate or low relief..$^{16}$ The area of gulf depression was probably a land area of similarly worndown surface before it was depressed.

Since their upheaval the coastal mountain ranges have been liberally dissected, and their outwashed detritus, along with much more that was brought from other ranges farther inland by the Pajaro and Salinas rivers, has been swept into the gulf of depression, thus filling up the inner part and converting it into a low plain, but leaving the outer part, less filled, as the existing bay. Hence, it is not to be expected that the submarine slope of the bay should still exhibit any close imitation of the form given to it by the depression of the former land surface. ${ }^{17}$ The slopes of depression must have been much built up by the inwashed sediments, which should have, during their accumulation, assumed a form determined by the movements of the sea water, either in general drifts or in more localized currents, both of which may have been spurred to greatest activity during severe storms. And be it noted that the form of the bay is admirably adapted to the development of an outgoing bottom current to compensate for an inward drift of the surface waters under the action of severe onshore winds. ${ }^{18}$ It is possible that the shore waters, made turbid at such times by wave action, would thus gain an increased specific gravity that would facilitate their descent into the colder water of the depths.

This explanation is at present altogether hypothetical for the greater length of the Monterey mock valley, but it is almost demonstrably true for the inner two or three miles, which are well shown as to form, depth, and deposits on Galliher's admirable lithologic map of the bay, based on a U. S. Coast and Geodetic Survey chart. ${ }^{19}$ This short innermost part of the 65-mile mock valley is narrow, steepsided, and well defined, as shown by 5 -fathom contours to a depth of

${ }_{16}$ Robin Willis: Physiography of the California Coast Ranges, Bull. Geol. Soc. of America, Vol. 36, 1925, pp. 64I-678.

${ }_{17}$ A. C. Lawson briefly suggested 40 years ago that the Monterey submarine valley is a trough of deformation, but he did not give special consideration to its modification by postdeformational deposition. See "The Geology of Carmelo Bay," Univ. of California Publs. in Geol., Vol. I, I893-1896, pp. $1-59$.

18 The action of such a bottom current has been appealed to by Bailey Willis in explanation of a submarine valley below the east coast of the Mediterranean island of Cyprus. See his letter on "A Submarine Trough off the Coast of Cyprus," Geogr. Journ., Vol. 79, 1932, pp. 349-351.

${ }^{19} \mathrm{E}$. W. Galliher: Sediments of Monterey Bay, California, Mining in California, Vol. 28, 1932, pp. 42-79. 
5o fathoms. Its depth is less than Ioo fathoms, and it is bordered by a smooth and shallower sea floor, which slopes gradually from the shore to about 30 fathoms. It is inconceivable that such a feature could have been kept open without the aid of a storm-driven, outsweeping current during the last Glacial lowering and rising of sea level. Even today the shore drift would fill up the head, unless, as Tangier Smith well said, the valley has "been formed, or at least kept open, by some cause now in operation." Indeed, if minutely accurate surveys of the valley head could be made, it would probably be found to be somewhat longer and deeper during stormy winters and shorter and shallower during the fine weather of summers.

The fact that the valley head, as well as the adjoining shallower sea floor, is shown on Galliher's map to be covered with "very fine sand," as determined by fair-weather dredging, does not militate in the least against the temporary action of such a localized bottom current as is here inferred; for fine sediments might be swept away whenever a fairly active, storm-driven bottom current is at work, only to be replaced by similar sediments when the current weakens or comes to rest. Other significant features of sediment distribution are shown on the map, but their explanation had best be left to those who observed and charted them.

It is only by individual study of many submarine valleys in close connection with the geological history of their coast that their origin can be determined; and when thus determined it is highly probable that they will be found to have many diverse and somewhat complicated origins. This paper is offered as a small contribution to such individual study. 